\title{
HYBRID SOLAR HEAT PUMP SYSTEM FOR WATER HEATING
}

\author{
Rodrigo A. Jordan ${ }^{1}$, Johnny T. Yamasaki ${ }^{2 *}$, Vivaldo Silveira Júnior ${ }^{3}$, Eduardo C. B. Dória ${ }^{4}$
}

${ }^{2 *}$ Corresponding author. Universidade Federal da Grande Dourados/ Dourados - MS, Brasil.

E-mail: johnnyyamasaki@ufgd.edu.br | ORCID ID: https://orcid.org/0000-0002-7315-6650

\section{KEYWORDS}

heat pump, solar collector, thermal energy.

\begin{abstract}
A comparative test of water heating between the hybrid system - solar collector with heat pump - and a system with conventional supplementary heating - with high electric power was performed. For this, a small capacity heat pump was installed, which was later installed together with a solar heating system, composed of a $250 \mathrm{~L}$ thermal reservoir and three thermoplastic collector plates. Tests were carried out to evaluate the COP of the heat pump and the energy consumption of the solar heating system operating with the heat pump and with an electrical resistance of $3000 \mathrm{~W}$. In the laboratory tests, the heat pump presented an average COP of 2.15. In the field tests, the energy consumption of the solar system with heat pump was $54.9 \%$ lower when compared to the tests in which electrical resistance was used as a source of supplementary heating.
\end{abstract}

\section{INTRODUCTION}

Demand for energy has been continuously increasing, whether due to population increase or growth in individual needs, as well as strong dependence regarding on nonrenewable sources (Zafar \& Dincer, 2014). In fact, according to IEA (2016), the energy matrix of the energies consumed in the world is predominantly non-renewable, mainly petroleum, coal and natural gas, corresponding to $66.50 \%$ of the energy consumed on the planet. Kyoto and Montreal Protocols (Reis, 2012), which aims to persuade signatory countries reducing the damage to the ozone layer and the carbon dioxide emission into the atmosphere, so that the use of renewable energy be intensified.

In Brazil, until 2014, the industrial sector experienced a relative stability; while in the commercial and residential sectors there was an increase in electricity consumption. Between 2005 and 2014, the commercial sector demanded an increase of $5.9 \%$ in electric energy, while the residential sector increased by $13 \%$ compared to other energy sources, such as natural gas and charcoal (Brasil, 2015). In addition, the increase in residential population, estimated by the Ministry of Mines and Energy, could lead to an increase of about 15 million households by 2020. This increase has an impact on the greater possession of domestic equipment, with consequent increase in residential electric consumption (Brasil, 2011).

With this in mind, companies and researchers seek the most efficient and optimized use of energy (Akbulut et al., 2016), aiming to the more intense use of renewable energies, in order to reduce previously mentioned environmental impacts. Solar (Yadav et al., 2014), geothermal (Ratlamwala et al., 2012; Safa et al., 2015), and wind Systems ( $\mathrm{Li}$ et al., 2013) are used individually or together in hybrid systems in order to reduce the impacts to the concessionaire conventional electricity network and, of course, reducing the costs of those who propose to use such equipment.

The heat pump has been introduced in several researches of hybrid systems, such as in Li et al. (2013), Tagliafico et al. (2012), Kim et al. (2013) and Zhao et al. (2014). The heat pump is more efficient when compared to other sources for heating, such as direct use of electricity and combustion. Although the heat pump is not a recent technology, its concept is still less widespread in some parts of the world (Staffell et al., 2012). And according to Hepbasli \& Kalinci (2008), water heating is one of the most responsible for the consumption of electricity, along with lighting and air conditioning.

The heat pump performance coefficient depends on the following factors (Jordan et al., 2016; Zhao et al., 2014, Safa et al., 2015, Akbulut et al., 2016): heat source temperature, condenser and water for consumption temperature, refrigerant fluid used, as well as constructive characteristics of the heat pump.

Solar panels and heat pumps are very promising systems for heating air and water, and can form hybrid systems, in serial or in parallel. The hybrid system can seek efficiencies balancing of the solar panel and the coefficient

\footnotetext{
${ }^{1}$ Universidade Federal da Grande Dourados/ Dourados - MS, Brasil.

${ }^{3}$ Universidade Estadual de Campinas/ Campinas - SP, Brasil.

${ }^{4}$ BPlan Consultoria e Transfrigor do Brasil/ Campinas - SP, Brasil.

Received in: 6-9-2017

Accepted in: 4-3-2019
} 
of performance (COP) of the heat pump. Most studies deal with direct expansion systems, for the production of water at temperatures of $45^{\circ} \mathrm{C}$, for air conditioning or water heating (Tagliafico et al., 2012).

In this context, the present study presents the assembly, in the field, of a prototype for water heating using solar collectors, using two configurations distinct and parallel for the supplementary heating. This prototype was tested in both configurations, obtaining data on final water temperature and energy consumption of the supplementary heating, making possible the comparative performance of each configuration.

\section{MATERIAL AND METHODS}

The heat pump used was a prototype assembled exclusively for the research, using the following components (Figure 1): a) compressor, Embraco manufacturer, EMI 60HER model, 1/6 HP, $220 \mathrm{~V}$ voltage, $60 \mathrm{~Hz}$, hermetic, piston compression; b) capillary tube with drier filter; c) evaporator ( $1 / 4 \mathrm{HP}$ of commercial reference) with 1/30 HP air forcing; (d) a shell-tube condenser, mounted with a $15 \mathrm{~m}$ of copper tube $1 / 4$ " diameter, coiled in a serpentine form, enclosed in a $50 \mathrm{~mm}$ diameter PVC tube shell. The refrigerant used was the R134a.

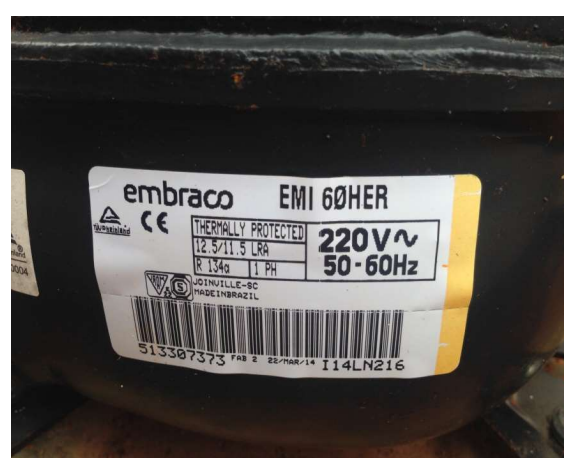

a) Compressor EMI 60 HER

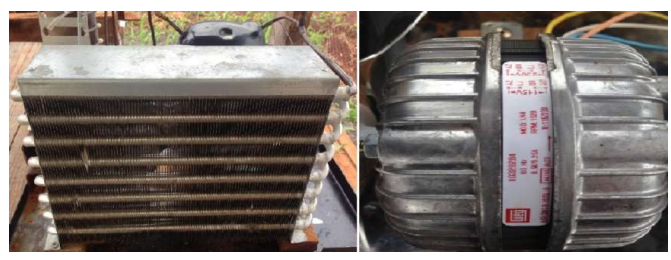

c) Evaporator

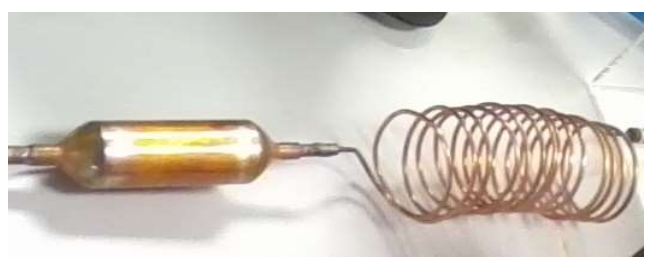

b) Capillary tube with drier filter

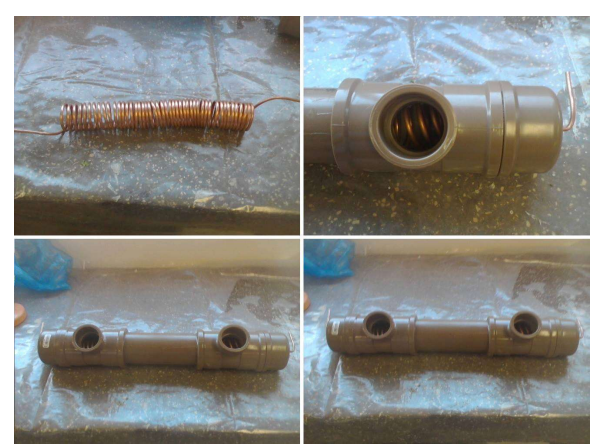

d) Shell-tube condenser

FIGURE 1. Components used in the heat pump.

After assembly, the heat pump was tested in the laboratory to determine the heating capacity and the coefficient of performance (COP), under thermosiphon circulation conditions (Figure 2). This stage was carried out in the Laboratory of Energy and Thermodynamics of the Faculty of Agrarian Sciences (Faculdade de Ciências Agrárias, FCA), Federal University of Grande Dourados (Universidade Federal da Grande Dourados, UFGD). For this purpose, the heat pump was connected to a $184 \mathrm{~L}$ reservoir, insulated with a $10 \mathrm{~mm}$ thick expanded polyurethane blanket. Three trials were carried out, with a duration of 5 hours, always starting with the same temperature value $\left(22{ }^{\circ} \mathrm{C}\right)$, measured with a PT100 probe. At the end the homogenized temperature of the tank was measured. The coefficient of performance (COP) was obtained through [eq. (1)]. 


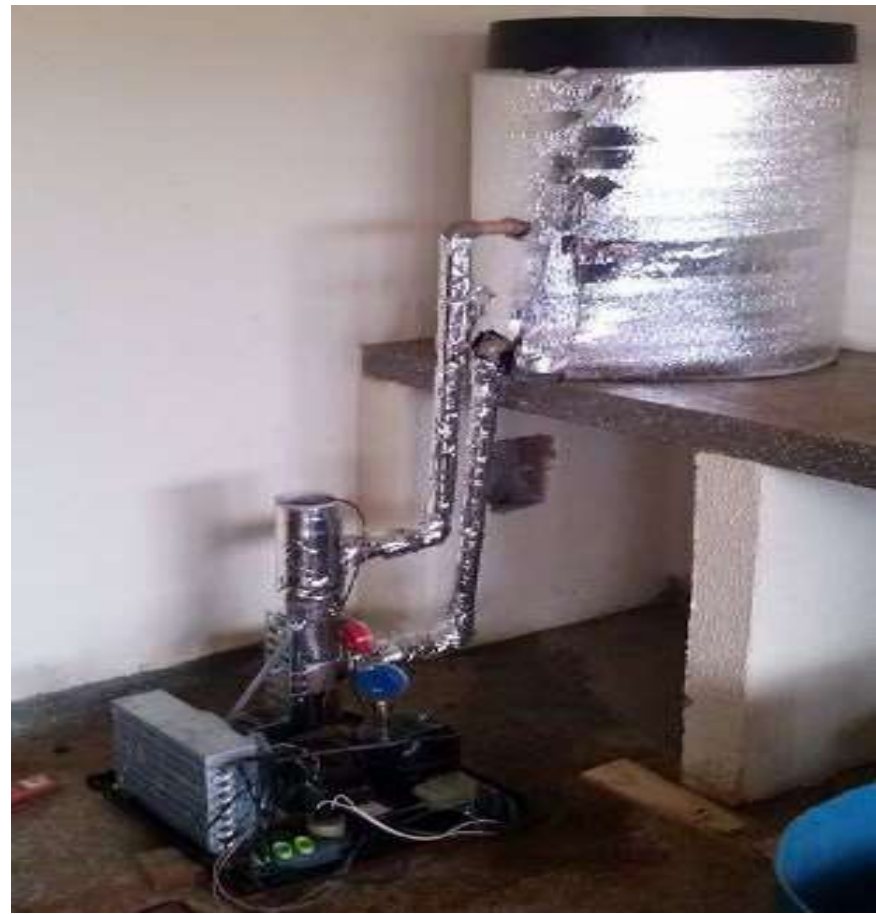

FIGURE 2. Laboratory heat pump test.

$$
\mathrm{COP}=\frac{Q_{H}}{W}
$$

Where,

$\mathrm{COP}=$ coefficient of performance;

$\mathrm{Q}_{\mathrm{H}}=$ heat stored in the water of the thermal reservoir $(\mathrm{kJ})$,

$\mathrm{W}=$ Heat pump work $(\mathrm{kJ})$.

$$
Q_{H}=w w \cdot C_{p} \cdot\left(T_{f}-T_{i}\right)
$$

Where,

$\mathrm{ww}=$ water weight of the reservoir $(\mathrm{kg}) ;$

$\mathrm{C}_{\mathrm{p}}=$ water specific heat at constant pressure $\left(\mathrm{kJ} \mathrm{kg}^{-1}{ }^{\mathrm{o}} \mathrm{C}^{-1}\right)$;

$\mathrm{T}_{\mathrm{f}}=$ homogenized final water temperature $\left({ }^{\circ} \mathrm{C}\right)$,

$\mathrm{T}_{\mathrm{i}}=$ initial water temperature $\left({ }^{\circ} \mathrm{C}\right)$.

The work was determined based on the energy consumption (Equation 3). For the measurement of electricity, an hour meter ampere, model $\mathrm{AH} 3$, brand Valexcell was used. The energy consumed in $\mathrm{kWh}$ was determined by [eq. (4)]. Therefore, the power factor of the heat pump was corrected to 1 , with the installation of a capacitor of $15 \mu \mathrm{F}$.

$$
\begin{aligned}
& W=C_{E} \cdot 3600 \\
& C_{E}=\frac{\text { Ah.V }}{1000}
\end{aligned}
$$

Where,

$\mathrm{C}_{\mathrm{E}}=$ energy consumption $(\mathrm{kWh})$;

$\mathrm{Ah}=$ ampere-hour measured during the test (Ah),

$\mathrm{V}=$ network voltage $(\mathrm{V})$.

After the laboratory tests, the heat pump was installed together with the solar heating system for the field tests (Figure 3), at coordinates $22^{\circ} 11^{\prime} 45^{\prime \prime} \mathrm{S}$ and $54^{\circ}$ 55 ' 18 " N. The solar heating system, manufactured by Alpina Thermoplastics, was composed of three flat plastic collectors, model 1003, of $1.05 \mathrm{~m}^{2}$ each, connected to a thermally insulated reservoir (boiler) with a volume of $250 \mathrm{~L}$.

Initially, it was attempted to install the heat pump in series with the solar collectors - hybrid system. However, as the condensation pressure became very high, it was necessary to switch to the parallel installation with forced circulation, using a small water pump, used in washing machines (model BAV220, manufacturer Honewell, of $34 \mathrm{~W}$ of power), which was installed at the condenser output (Figure 4). 


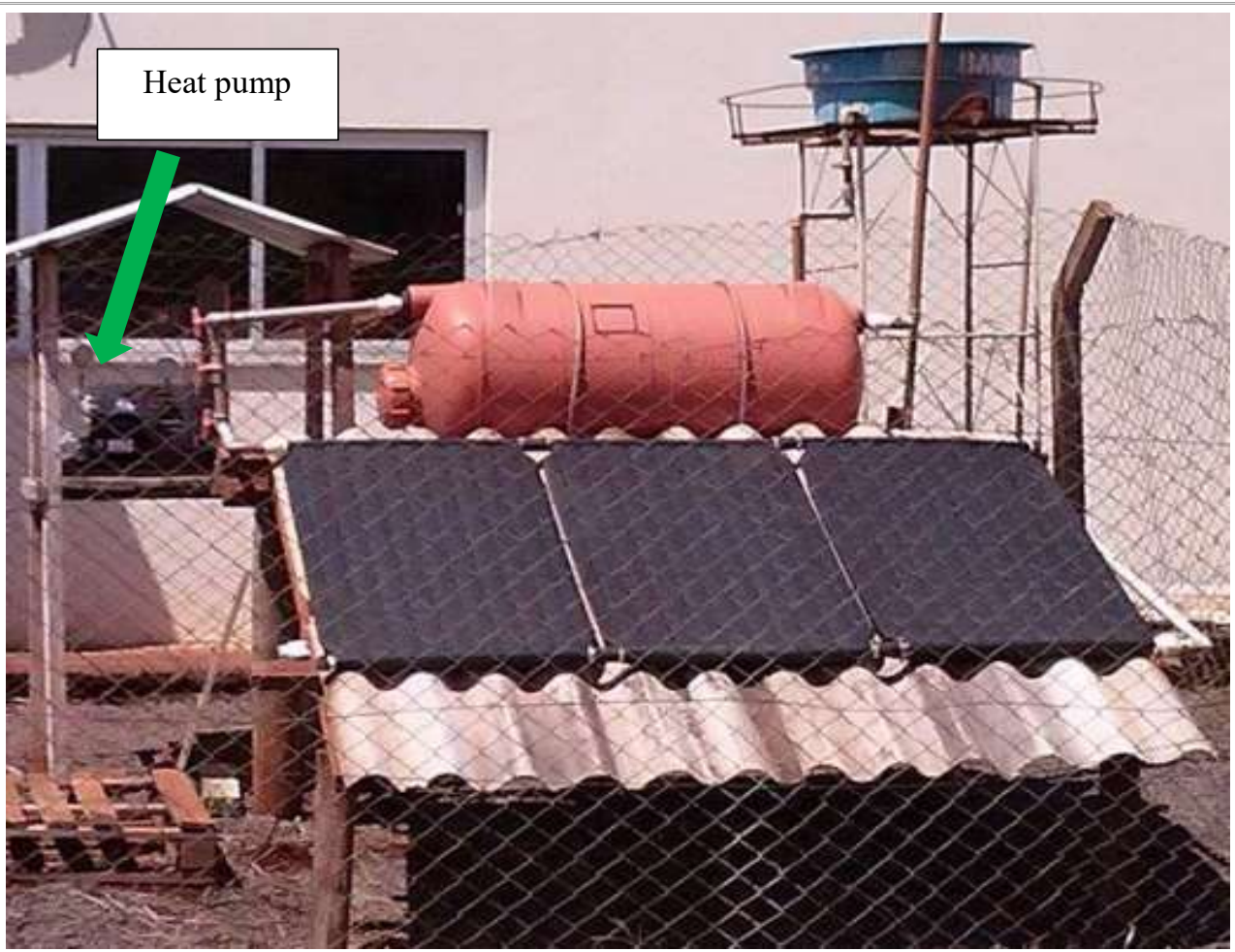

FIGURE 3. Complete system assembled for field testing.

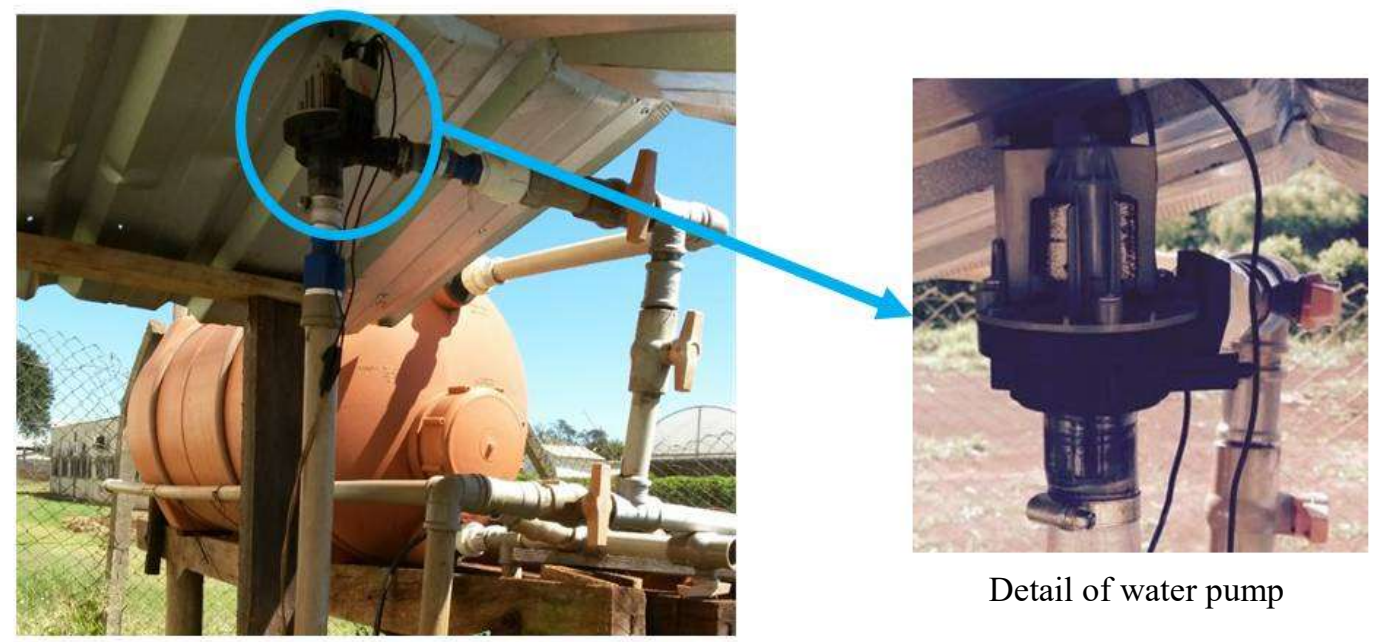

FIGURE 4. Water pump for forced circulation.

The installation of the heating system was done in a way that enabled four operating configurations: without supplementary heating with natural circulation, with supplementary resistive heating, with supplementary heating by heat pump with forced circulation and without supplementary heating with forced circulation. For this, the hydraulic installation was provided with valves at specific points to enable these changes (Figure 5). 


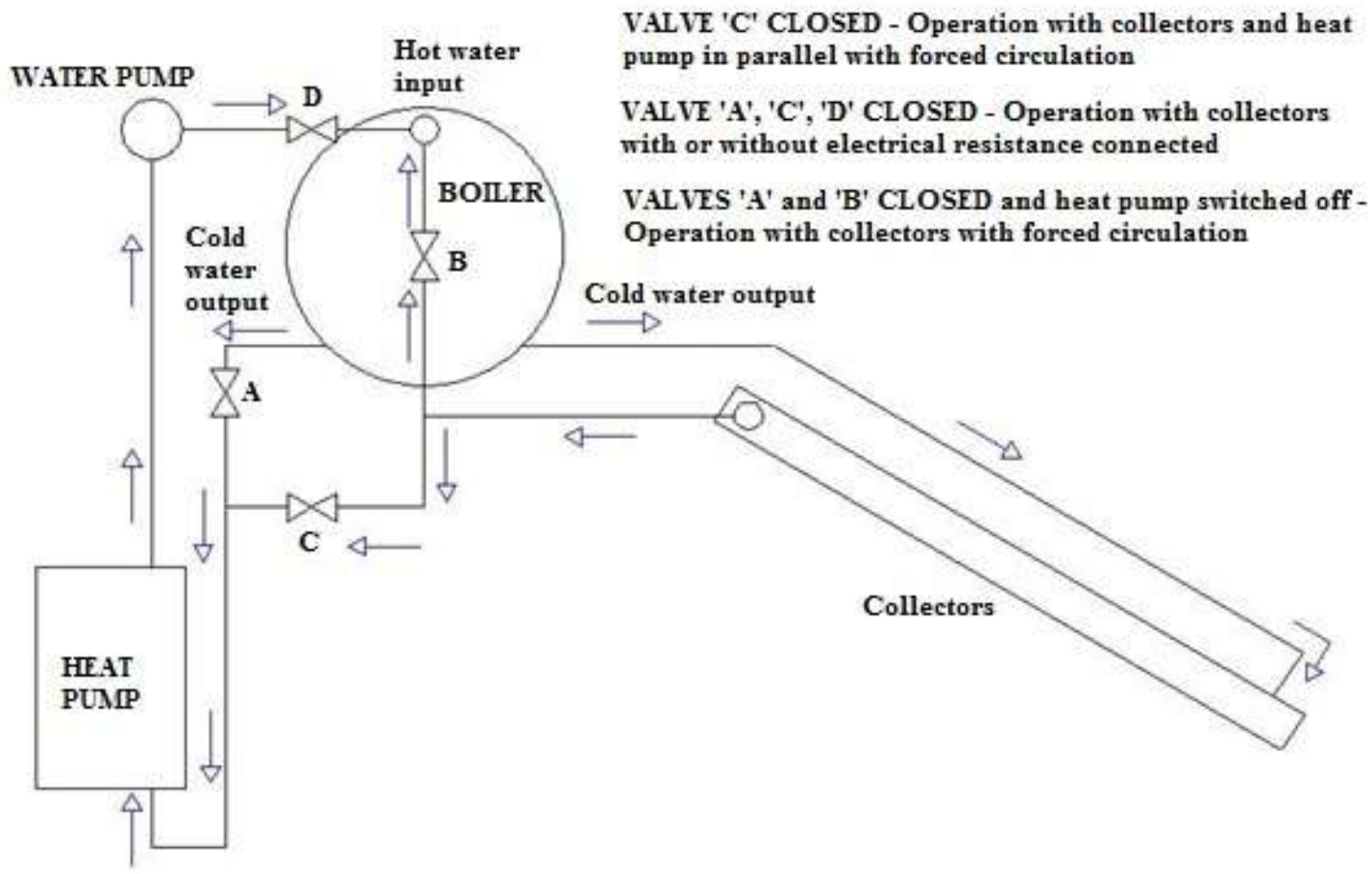

FIGURE 5. Hydraulic configuration of the hybrid system.

In addition, an electric control panel was set up to select the electrical components in each configuration. In this frame was installed a digital temperature controller, to operate both the heat pump and the electrical resistance in each mode of operation, which was set at $50^{\circ} \mathrm{C}$.

The installation of the solar collectors was carried out following the manufacturer's recommendation (local latitude $+10^{\circ}$ ), with a north orientation, with a slope angle of $33^{\circ}$. The electrical resistance used in the reservoir was not offered with the set, being purchased separately, had heating power of $3000 \mathrm{~W}$.

The tests in each configuration (Table 1) were repeated 4 times, performed on consecutive days, except for cloudy or rainy days, with tests beginning on $05 / 20 / 2015$ and ending on 06/29/2015. All trials lasted for 9 hours, starting at $8 \mathrm{am}$ and finishing at $5 \mathrm{pm}$. At the beginning of each test, the initial temperature of the water was recorded by the temperature reading of the digital temperature controller, which sensor was installed at the midpoint of the thermal reservoir. At the end of the test, the final temperature, also read in the temperature controller, was taken. The controller probe was installed in the central part of the thermal reservoir at the same point of the electrical resistance installation.

TABLE 1. Test configurations that were performed in the field.

\begin{tabular}{cccc}
\hline Test & Heat pump & Water pump & Electrical resistance \\
\hline T1 & Active & Active & Inactive \\
\hline T2 & Inactive & Active & Active \\
\hline T3 & Inactive & Active & Inactive \\
\hline T4 & Inactive & Inactive & Inactive \\
\hline
\end{tabular}

The total heat transferred to the water by the heating system in each test was calculated by [eq. (2). To measure the energy consumption of supplementary heating systems, the same hour meter employed in the laboratory tests was used, and the total energy consumed, equivalent to the work used in the supplementary heating systems, determined by [eq. (3)].

The energy produced/energy consumed ratio $(\mathrm{QH} /$ W) was used as a parameter to compare the performance of the solar heating system in each configuration with support system.

\section{RESULTS AND DISCUSSION}

Table 2 shows the results for the laboratory tests with the heat pump, where the average COP was 2.05. Satisfactory value when compared to the results of $\mathrm{Li}$ et al. (2013), which obtained values between 1.4 and 4.4 for a heat pump installed in a solar hybrid system for water heating, considering that it had an electric power three times greater. Kim et al. (2013) obtained COP values between 2.12 and 2.77 for a $10.55 \mathrm{~kW}$ heat pump operating with $\mathrm{CO}_{2}$ in a solar hybrid geothermal system for water heating.

TABLE 2. Results of laboratory tests.

\begin{tabular}{cccc}
\hline Test & $\mathrm{W}(\mathrm{kJ})$ & $\mathrm{Q}_{\mathrm{H}}(\mathrm{kJ})$ & $\mathrm{COP}$ \\
\hline 1 & 6249 & 11536 & 1.85 \\
\hline 2 & 5468 & 11535 & 2.11 \\
\hline 3 & 5468 & 11920 & 2.18 \\
\hline Average & 5728 & 11664 & 2.05 \\
\hline
\end{tabular}

Table 3 shows the average values of energy consumption for field tests, according to each operation configuration (Table 1). Table 4 shows the average values of the water temperature of the thermal reservoir in each test. 
TABLE 3. Results of the average energy consumption in each test.

\begin{tabular}{lccc}
\hline Test & $\begin{array}{c}\text { Consumption } \\
(\mathrm{Ah})\end{array}$ & $\begin{array}{c}\text { Consumption } \\
(\mathrm{kWh})\end{array}$ & $\begin{array}{c}\text { Consumption } \\
(\mathrm{kJ})\end{array}$ \\
\hline T1 & 9.25 & 2.035 & 7326 \\
\hline T2 & 20.5 & 4.510 & 16236 \\
\hline T3 & - & $0.306\left(^{*}\right)$ & 1102 \\
\hline T4 & n.a. & n.a. & n.a. \\
\hline
\end{tabular}

Obs.: Calculated based on pump power at operating time; na.: not applicable.

TABLE 4. Temperature average values of the thermal reservoir in each test.

\begin{tabular}{cccc}
\hline Test & $\mathrm{T}$ initial $\left({ }^{\circ} \mathrm{C}\right)$ & $\mathrm{T}$ final $\left({ }^{\circ} \mathrm{C}\right)$ & $\Delta \mathrm{T}\left({ }^{\circ} \mathrm{C}\right)$ \\
\hline $\mathrm{T} 1$ & 24.7 & 49.2 & 24.5 \\
\hline $\mathrm{T} 2$ & 26.0 & 48.5 & 22.5 \\
\hline $\mathrm{T} 3$ & 25.0 & 28.9 & 3.9 \\
\hline $\mathrm{T} 4$ & 24.1 & 26.6 & 2.5 \\
\hline
\end{tabular}

The final values of water temperature obtained in the tests with the use of supplementary heating systems (heat pump and electric resistance) were close to the value adjusted in the temperature controller. In tests 3 and 4, without supplementary heating system, these temperature values did not exceed $20{ }^{\circ} \mathrm{C}$, demonstrating the importance of the supplementary heating system.

The use of forced circulation (T3) provided a higher temperature gain and a $56 \%$ increase in the amount of thermal energy stored (Table 5) when compared to natural circulation (T4). Jordan et al. (2015) and Pandey et al. (2015) have shown that increasing the flow up to a certain value, contributes to the increase of solar collector efficiency.

TABLE 5. Average values of energy produced and energy consumed and the relation between them.

\begin{tabular}{cccc}
\hline Teste & $\begin{array}{c}\text { EP - Energy Produced } \\
(\mathrm{kJ})\end{array}$ & $\begin{array}{c}\text { EC - Energy } \\
\text { Consumed (kJ) }\end{array}$ & EP/EC \\
\hline T1 & 24500 & 7326 & 3.34 \\
\hline T2 & 22500 & 16236 & 1.39 \\
\hline T3 & 3900 & 1102 & 3.54 \\
\hline T4 & 2500 & n.a. & n.a. \\
\hline
\end{tabular}

The electric power consumption of the configuration operating with forced circulation heat pump (T1) was $54.9 \%$ lower than the configuration using the $3000 \mathrm{~W}$ of electrical resistance as supplementary heating (T2). This, due to the higher efficiency of the heat pump, which could generate more than double its electrical power in thermal energy (Table 2). Li et al. (2013) mention a saving potential of up to $79 \%$ with the use of heat pumps in heating systems.

In addition to reducing energy consumption, we have the benefit of power reduction, resulting in a much lower current. While the average heat pump current was $1.5 \mathrm{~A}$, as demonstrated in laboratory tests, the rated current of the electrical resistance was $13.6 \mathrm{~A}$, nine times higher.

Comparing the COP mean value of the heat pump obtained in the laboratory, with the result of Table 5, we verified that the heat pump was responsible for at least $60 \%$ of the thermal load accumulated in the $\mathrm{T} 1$ test.
However, according to Jordan et al. (2016) the increase of the water flow in the condenser reduces the condensation temperature, raising the COP. Thus, forced circulation may have led to an improvement in COP, which means that the contribution of the heat pump was greater.

This can be verified when the same analysis was done for the electric resistance test (T2). Considering that all the electric energy consumed was converted to heat, which is reasonable in the case of an electric resistance, the supplementary heating was responsible for $70 \%$ of the accumulated thermal load. Thus, it is estimated that the COP of the heat pump with forced circulation was 2.34 , an increase of almost $9 \%$.

If we compare the result of the test without supplementary heating with natural circulation (T4) to the heat pump test (T1), considering that the energy accumulated in T4 test is what the solar system can generate alone, assuming that the difference for energy accumulated in $\mathrm{T} 1$ is the one generated by the supplementary heating, it could be stated that the heat pump can generate more than $90 \%$ of the thermal energy, which converge the results obtained by Kim et al. (2013). However, not all of this accumulated energy increase can be credited for the direct action of the heat pump, that is, the heat generated by it. But, indirectly, due to the increase of the temperature gradient in the thermal reservoir, implying an increase in thermosiphon circulation, thus improving the efficiency of the collectors.

Regarding the climatic conditions (Table 6), it is possible to assume that they were not significant, or they presented small variation among the tests. The average ambient temperature was slightly higher in the electrical resistance test (T2). But, on the other hand, the radiation was $5 \%$ lower than in the heat pump test (T1).

TABLE 6. Climatic conditions, average values, during the tests.

\begin{tabular}{ccccc}
\hline Test & $\begin{array}{c}\mathrm{T}_{\text {average }} \\
\left({ }^{\circ} \mathrm{C}\right)\end{array}$ & $\mathrm{RH}_{\text {average }}(\%)$ & $\begin{array}{c}\mathrm{V}_{\text {average }} \\
(\mathrm{m} / \mathrm{s})\end{array}$ & $\begin{array}{c}\text { Radiation } \\
\left(\mathrm{MJ} / \mathrm{m}^{2}\right)\end{array}$ \\
\hline $\mathrm{T} 1$ & 20.4 & 82.0 & 0.62 & 6.3 \\
\hline $\mathrm{T} 2$ & 22.0 & 77.3 & 0.75 & 6.0 \\
\hline $\mathrm{T} 3$ & 20.6 & 74.8 & 0.70 & 6.3 \\
\hline $\mathrm{T} 4$ & 21.3 & 74.0 & 0.69 & 6.6 \\
\hline
\end{tabular}

Obs.: Data from the weather station of Embrapa Agropecuaria Oeste, coordinates $22^{\circ} 16^{\prime} 30^{\prime \prime} \mathrm{S}, 54^{\circ} 49^{\prime} 00^{\prime \prime} \mathrm{W}, 408 \mathrm{~m}$. Accessed through the website

http://www.cpao.embrapa.br/clima/?lc=site/bancodados/construtor-basico (EMBRAPA, 2015).

\section{CONCLUSIONS}

The heat pump provided a significant reduction in electric power consumption for supplementary heating in the solar heating system. With a power of just over onetenth the power of the electric resistance, the heat pump was able to produce the same temperature level at the end of the heating process, without damaging the quality of the heating. 


\section{REFERENCES}

Akbulut U, Kincay O, Utlu Z (2016) Analysis of a wall cooling system using a heat pump. Renewable Energy 85:540-553.

Brasil - Ministério de Minas e Energia (2011) Plano Decenal de Expansão de Energia 2020. Empresa de Pesquisa Energética, 319 p.

Brasil - Ministério de Minas e Energia (2015) Balanço Energético Nacional 2015, ano base 2014. Empresa de Pesquisa Energética, 155 p.

Embrapa (2015) Guia clima - Estação da Embrapa Agropecuária Oeste - Embrapa. Available: http://www.cpao.embrapa.br/clima/?lc=site/bancodados/construtor-basico. Accessed: Aug 15, 2015.

Hepbasli A, Kalinci Y (2008) A review of heat pump water heating systems. Renewable and Sustainable Energy Reviews 13:1211-1219.

IEA - International Energy Agency (2016) Key World Energy Statistics. Total Final Consumption. Available: https://www.iea.org/publications/freepublications/publicati on/KeyWorld2016.pdf. Accessed: Jun 24, 2016.

Jordan RA, Seye O, Motomiya AVA (2015) Influência da vazão de água sobre o rendimento de um coletor solar plano construído em termoplástico. Engenharia Agrícola 35(4):665-675.

Jordan RA, Cortez LAB, Barbin DF, Lucas Junior J (2016) Heat pump for thermal power production in dairy farm. Engenharia Agrícola 36(5):779-791.

Kim W, Choi J, Cho H (2013) Performance analysis of hybrid solar-geothermal $\mathrm{CO}_{2}$ heat pump system for residential heating. Renewable Energy 50:596-604.

Li QY, Chen Q, Zhang X (2013) Performance analysis of a rooftop wind solar hybrid heat pump system for buildings. Energy and Buildings 65:75-83.
Pandey AK, Tyagi VV, Rahim NA, Kaushik SC, Tyagi SK (2015) Thermal performance evaluation of direct flow solar water heating system using exergetic approach. Journal of Thermal Analysis and Calorimetry 121:1365-1373.

Ratlamwala TAH, Gadalla MA, Dincer I (2012) Thermodynamic analyses of an integrated PEMFCTEARS-geothermal system for sustainable buildings. Energy and Buildings 44:73-80.

Reis RVM (2012) Análise experimental comparativa entre uma bomba de calor e uma resistência elétrica como dispositivo de apoio de energia para um aquecedor solar de água. Tese Doutorado, Belo Horizonte, Universidade Federal de Minas Gerais.

Safa AA, Fung AS, Kumar R (2015) Heating and cooling performance characterisation of ground source heat pump system by testing and TRNSYS simulation. Renewable Energy 83:565-575.

Staffell I, Brett D, Brandon N, Hawkes A (2012) A review of domestic heat pumps. Energy \& Environmental Science 5:9291-9306.

Tagliafico LA, Scarpa F, Tagliafico G, Valsuani F (2012) An approach to energy saving assessment of solar assisted heat pumps for swimming pool water heating. Energy and Buildings 55:833-840.

Yadav S, Kaushal M, Varun, Siddhartha (2014) Exergetic performance evaluation of solar air heater having arc shape oriented protrusions as roughness element. Solar Energy 105:181-189.

Zafar S, Dincer I (2014) Energy, exergy and exergoeconomic analyses of a combined renewable energy system for residential applications. Energy and Buildings 71:68-79.

Zhao Z, Feng W, Mi H, Cheng H, Yun L (2014) Experimental study of a solar assisted ground source heat pump for heating. Journal of Automation and Control Engineering 2(2):146-149. 